\title{
The Improvement reasoning ability of students to mathematic and logic through colour chip worksheet in the basic education unit in Tanjung Morawa
}

\author{
Putri Khairiah Nasution ${ }^{1 *}$, Aghni Syahmarani ${ }^{1}$, Maulida Yanti ${ }^{1}$ \\ ${ }^{1}$ Departement of Mathematics, Universitas Sumatera Utara, Medan, Indonesia \\ *Email: putrikhairiah09@gmail.com
}

\begin{abstract}
Learning media is tools for teaching and learning process. Related to the use of instructional media as a component that can help teachers and students in the learning process. In learning mathematics at SDIT Deli Insani, there is still lack of learning media as a component in the learning process. The selection of the most appropriate media that must be considered to achieve the expected goals is to stimulate the ability to choose, increase communication power, stimulate independence, encourage motivation, and increase student creativity. The worksheet is a piece of learning media as well as an innovative game that can be carried around, the exam material is in accordance with the K-13 curriculum for elementary school students grade 1 to 4 . By taking a sample of students grade 3 and 4 consist of 30 students per class, done a pre-test about material of mathematics, then explained the use of color chip worksheets. Next, learned the material using a worksheet of color chips. And finally, a post test was conducted to measure up which students could absorb the material. The evaluation, carried out about 2 months after the training, the teachers and students have independently used a worksheet of color chips and the students' abilities significantly improved.
\end{abstract}

Keyword: Learning media, mathematic, worksheet

\begin{abstract}
Abstrak
Media pembelajaran secara umum adalah alat bantu proses belajar mengajar. Terkait dengan penggunaan media pembelajaran sebagai suatu komponen yang dapat membantu guru dan siswa dalam proses pembelajaran. Pada pembelajaran matematika di SDIT Deli Insani, masih kurang memanfaatkan media pembelajaran sebagai salah satu komponen dalam proses pembelajaran. Pemilihan media yang paling tepat yang harus diperhatikan untuk mencapai tujuan yang diharapkan yaitu menstimulasi kemampuan observasi, meningkatkan daya komunikasi, menstimulasi kemandirian, merangsang imajinasi, serta meningkatkan kreativitas siswa. Worksheet keping warna merupakan salah satu media pembelajaran sekaligus permainan inovatif yang bersifat portable, memuat materi matematika sesuai kurikulum K-13 untuk siswa SD kelas 1 sampat 4. Dengan mengambil sampel siswa kelas 3 (tiga) dan 4 (empat) dengan masing-masing berjumlah 30 siswa per kelas, dilakukan pre-test terkait materi pelajaran matematika secara tertulis, kemudian dijelaskan penggunaan worksheet keping warna dan mengambil worksheet yang sesuai dengan pre-test. Selanjutnya, mempelajari materi menggunakan worksheet keping warna. Dan terakhir, kembali dilakukan post test untuk mengukur sejauh mana siswa dapat menyerap materi. Tahap evaluasi, dilakukan sekitar 2 bulan setelah kegiatan pelatihan, para guru dan siswa sudah mandiri menggunakan worksheet keping warna dan kemampuan siswa naik secara signifikan.
\end{abstract}

Kata Kunci : Media Pembelajaran, Worksheet, Matematika

\section{PENDAhULUAN}

Dalam sistem pendidikan Nasional, tujuan instruksional pembelajaran dirumuskan dalam bentuk kompetensi, yakni kemampuan yang harus dicapai setelah siswa mengalami proses pembelajaran dalam satuan pendidikan tertentu. Badan Standar Nasional Pendidikan (BSNP) merumuskan bahwa standar kompetensi lulusan satuan pendidikan adalah kualifikasi kemampuan lulusan yang mencakup pengetahuan, sikap, dan keterampilan pada setiap satuan pendidikan yang terdiri dari satuan pendidikan dasar (SD/MI/SDLB/Paket A, SMP/MTs/ SMPLB/Paket B) dan satuan 
pendidikan menengah (SMA/MA/SMALB/Paket C, SMK/MAK) (Sanjaya, 2008). Salah satu standar kompetensi lulusan satuan pendidikan tersebut adalah menunjukkan kemampuan memecahkan masalah dalam kehidupan sehari-hari.

Matematika merupakan bidang studi dasar yang paling berpengaruh terhadap kemampuan penalaran siswa sehingga dalam proses pembelajaran dibutuhkan suatu alat atau media yang dapat membantu siswa memahami materi dengan lebih jelas dan menyenangkan. Sistem pembelajaran tidak hanya dapat dilakukan di dalam raung kelas, tetapi juga dapat dilakukan di luar kelas. Worksheet keping warna ini merupakan media pembelajaran atau alat peraga yang mudah dibawa berpindah tempat, mudah digunakan, dan juga worksheet memuat materi kelas 1 sampai 4 yang sesuai dengan kurikulum K-13.

Pada pelaksanaan pengabdian ini, tim pelaksana memilih lokasi pengabdian di Sekolah Dasar Islam Terpadu Deli Insani, Tanjung Morawa. Adapun permasalahan yang dihadapi oleh mitra yaitu:

1. Kurangnya media pembelajaran yang dapat meningkatkan penalaran siswa di bidang matematika dan logika.

2. Kurang luasnya pekarangan sekolah menyebabkan ruang gerak siswa terbatas untuk bermain di luar ruangan sehingga dibutuhkan media pembelajaran yang juga bisa berfungsi sebagai sarana bermain siswa secara indoor.

Dengan jumlah siswa/i yang mencapai 230 orang, media distribusi proses belajar mengajar yang efektif juga menjadi permasalahan bagi pihak sekolah. Saat ini, sekolah tersebut belum memiliki fasilitas dan prosedur standar dalam memanfaatkan alat peraga sebagai salah satu sarana proses belajar mengajar kepada siswa/i dan guru.

Berdasarkan pengamatan yang telah dilakukan, maka tim pelaksana merumuskan sekolah yang bersangkutan kurang memanfaatkan peran alat peraga matematika berupa worksheet keping warna dalam sarana transfer knowledge dan meningkatkan minat belajar sebagai pendukung kegiatan belajar mengajar. Tim pelaksana menyimpulkan bahwa ada beberapa masalah yang dihadapi oleh pihak sekolah dalam menggunakan alat peraga adalah sebagai berikut:

1. Sekolah Mitra belum memiliki alat peraga portable misalnya, seperti worksheet keping warna yang didedikasikan untuk kegiatan pembelajaran. Beberapa kegiatan untuk mempelajari matematika masih menggunakan buku secara teori.

2. Halaman/Pekarangan sekolah mitra kurang memadai untuk tempat bermain siswa, sehingga dibutuhkan media pembelajaran sekaligus berfungsi sebagai permainan inovatif yang dapat dilakukan di dalam ruangan

\section{METODE PELAKSANAAN}

Seperti yang telah dijelaskan di Bab Pendahuluan, bahwa penggunaan media pembelajaran yang belum ada serta kurang luasnya pekarangan sekolah untuk kegiatan bermain siswa. Maka pentingnya dikonsep suatu media pembelajaran yang sekaligus berfungsi sebagai permainan inovatif yang bersifat inovatif dan portable (mudah dipindah tempatkan). Adapun rincian kegiatan pengabdian masyarakat yang dilakukan di SDIT Deli Insani, Kecamatan Tanjung Morawa, Kabupaten Deli Serdang antara lain:

a. Survey awal dan melakukan identifikasi permasalahan, yaitu peninjauan lokasi mitra dengan menggali informasi tentang fasilitas apa saja yang sudah dimiliki sekolah serta apa saja yang belum dan sangat dibutuhkan sekolah untuk mendukung proses belajar mengajar. Sehingga tujuan pendidikan nasional berupa pencapaian kompetensi siswa dapat terwujud.

b. Perancangan alat peraga yang dapat diterapkan di ruang kelas dan di luar ruang. Dalam tahap ini, tim pelaksana mendiskusikan hal-hal apa saja yang akan diberikan untuk mendukung sistem pembelajaran dan juga dapat digunakan sebagai permainan inovatif di dalam maupun di luar ruang kelas. 
c. Pelatihan Guru dan Siswa. Pada tahap ini guru dan siswa akan diberikan pelatihan tata cara penggunaan alat peraga worksheet keping warna.

d. Evaluasi.

Pada tahap ini, guru dan siswa sudah mandiri menggunakan worksheet keping warna tanpa dibantu oleh tim pelaksana. Dalam tahap ini, tim pelaksana juga melakukan umpan balik yaitu mengumpulkan masukan terhadap kegiatan pengabdian kepada masyarakat yang telah dilakukan dengan cara pengisian angket kuesioner dan hasilnya para guru dan siswa merasa puas/terbantu dengan keberadaan worksheet keping warna.

Adapun partisipasi mitra dalam pelaksanaan Program Pengabdian kepada Masyarakat yaitu

a. Mitra ikut membantu pelaksanaan pengabdian kepada masyarakat

b. Guru ikut memperhatikan tim pelaksana ketika menjelaskan cara penggunaan media pembelajaran worksheet keping warna

c. Guru ikut mendampingi tim pelaksana ketika proses pembelajaran memakai worksheet keping warna

d. Guru tetap menggunakan alat worksheet keping warna ketika pembelajaran

e. Guru mengarahkan siswa menggunakan worksheet keping warna untuk permainan ketika waktu istirahat

f. Worksheet keping warna disimpan di perpustakaan agar siswa dapat dengan mudah melakukan peminjaman.

\section{HASIL DAN PEMBAHASAN}

Pengabdian pada masyarakat dengan dana NON PNBP Universitas Sumatera Utara dilakukan di SDIT Deli Insani Tanjung Morawa. Pada pengabdian masyarakat ini tim pelaksana juga dibantu oleh tiga orang mahasiswa S1 Matematika FMIPA USU, yang bernama Retno Budiarti (2018), Melisa Dayanti (2017) dan Mustika Rahayu (2015). Ketiga mahasiswa tersebut membantu tim pelaksana melakukan sosialisasi alat peraga yaitu worksheet keping warna kepada guru dan siswa. Adapun rincian kegiatan yang telah dilakukan di lokasi pengabdian, yaitu:

1. Survey awal dan melakukan identifikasi permasalahan di SDIT Deli Insani

Dalam kegiatan ini, tim pelaksana berdiskusi kepada kepala sekolah dan juga beberapa orang guru tentang permasalahan-permasalahan yang terjadi di SDIT Deli Insani. Kegiatan ini dilakukan pada 26 maret 2019 dan dilakukan perjanjian kerjasama antara mitra yaitu SDIT Deli Insani dengan tim pelaksana pada tanggan 28 maret 2019.

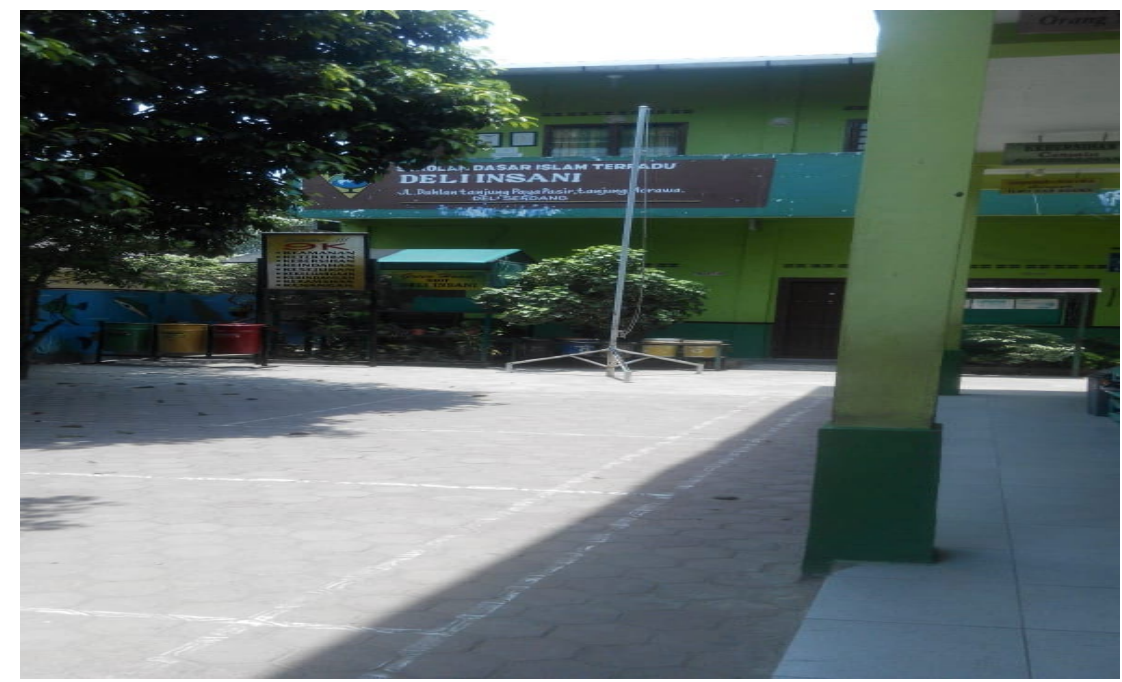

Gambar 3.1. Keadaan Sekolah SDIT Deli Insani, Tanjung Morawa 
Capaian dari kegiatan ini adalah mendapatkan solusi dari permasalahan yang terjadi di lokasi mitra SDIT Deli Insani yaitu merancang media pembelajaran sekaligus alat permainan yang bersifat portable yaitu dapat berpindah tempat dengan mudah, dapat diterapkan di dalam maupun luar kelas dan juga dapat digunakan secara individu dan berkelompok serta terjalinnya kerjasama antara tim pelaksana dan mitra.

2. Perancangan alat peraga yang dapat diterapkan di ruang kelas dan di luar ruang

Kegiatan kedua ini, tim pelaksana berdiskusi dan sepakat untuk memberikan media pembelajarn sekaligus berfungsi sebagai alat permainan yang dapat meningkatkan kemampuan penalaran siswa dalam mata pelajaran matematika. Media pembelajaran tersebut yaitu worksheet keping warna.

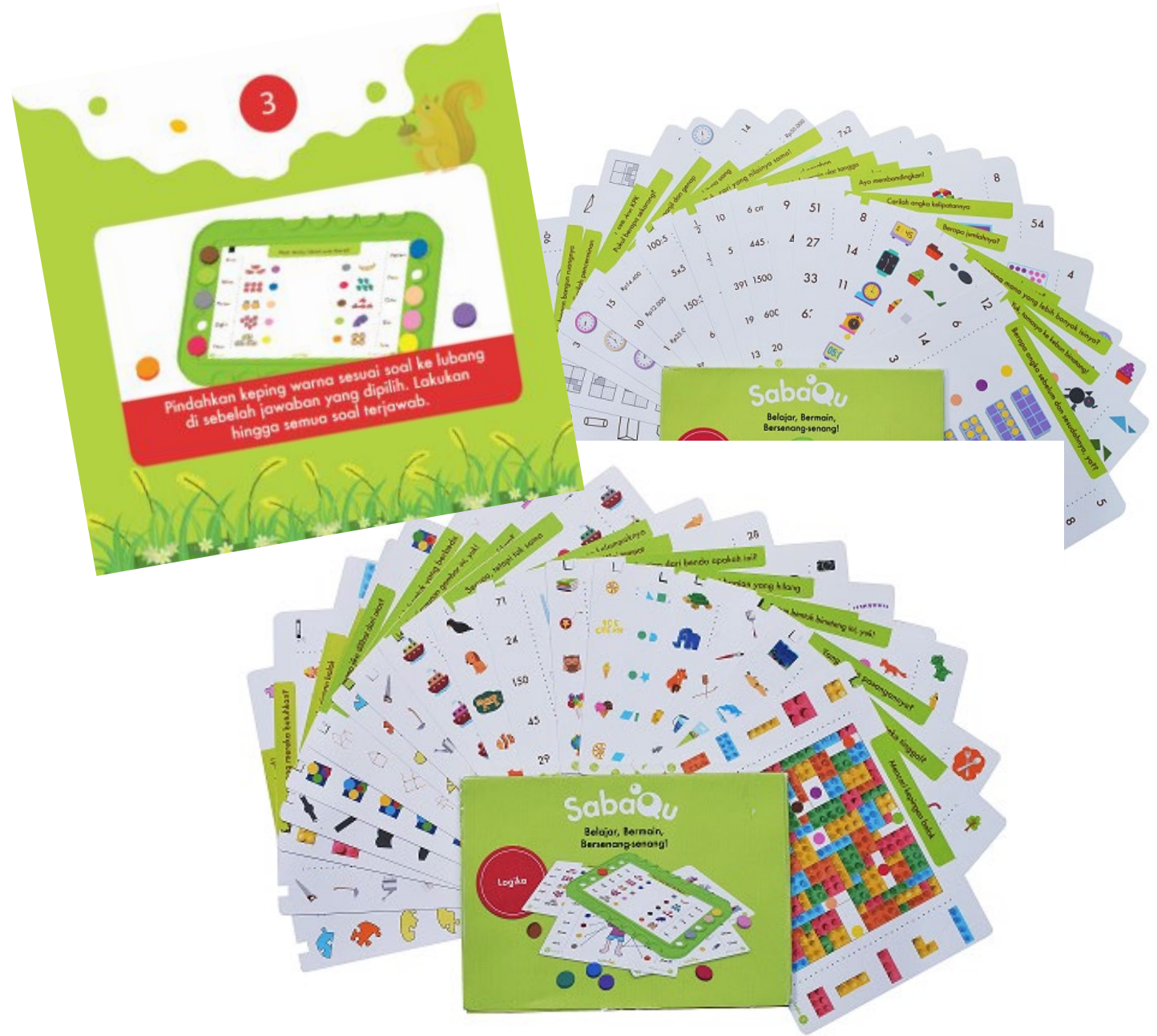

Gambar 3.2. Media Pembelajaran Sekaligus Permainan Ditransfer Kepada Kedua Mitra

Capaian kegiatan ini adalah mendapatkan media pembelajaran sekaligus permainan yang inovatif bersifat portable (dapat dengan mudah dipindah-tempatkan), dapat digunakan secara individu dan berkelompok, dapat digunakan di luar maupun di dalam ruangan, berisi materi pelajaran mulai dari kelas 1 sampai kelas 4 dengan bidang study matematika, logika, bahasa indonesia dan juga bahasa inggris.

3. Pelatihan Guru dan Siswa dalam menggunakan alat peraga yaitu worksheet keping warna Kegiatan ketiga ini dilakukan pada tanggal 1 Agustus 2019. Sebelum pelatihan menggunakan alat peraga, terlebih dahulu dilakukan pre test terhadap siswa kelas 3 dan 4 sesuai materi pelajaran pada masing-masing kelas tersebut. Soal pre test dibuat oleh tim pelaksana berdasarkan materi worksheet yang sesuai dengan materi pelajaran di kelas. Soal pre test dibagikan kepada siswa untuk dijawab kemudian dikumpulkan kembali dan dikoreksi oleh para 
mahasiswa pendamping kegiatan pengabdian masyarakat. Selanjutnya, dilakukan kegiatan pelatihan cara penggunaan media pembelajaran worksheet keping warna dan siswa kembali menyelesaikan soal pre test menggunakan worksheet keping warna secara berkelompok (1 kelompok : 3 orang). Ketika menyelesaikan kembali soal pre test dengan menggunakan worksheet keping warna, terlihat sikap antusias dari para guru dan siswa. Siswa nampak lebih rileks dalam mengerjakan soal serta tercipta kerjasama tim yang baik. Di akhir kegiatan ini dilakukan pemberian souvenir kepada 2 orang siswa yang memperoleh nilai pre test tertingi dan 3 kelompok yang dapat menyelesaikan worksheet keping warna dengan cepat dan tepat serta penyerahan 10 unit worksheet keping warna kepada pihak sekolah.

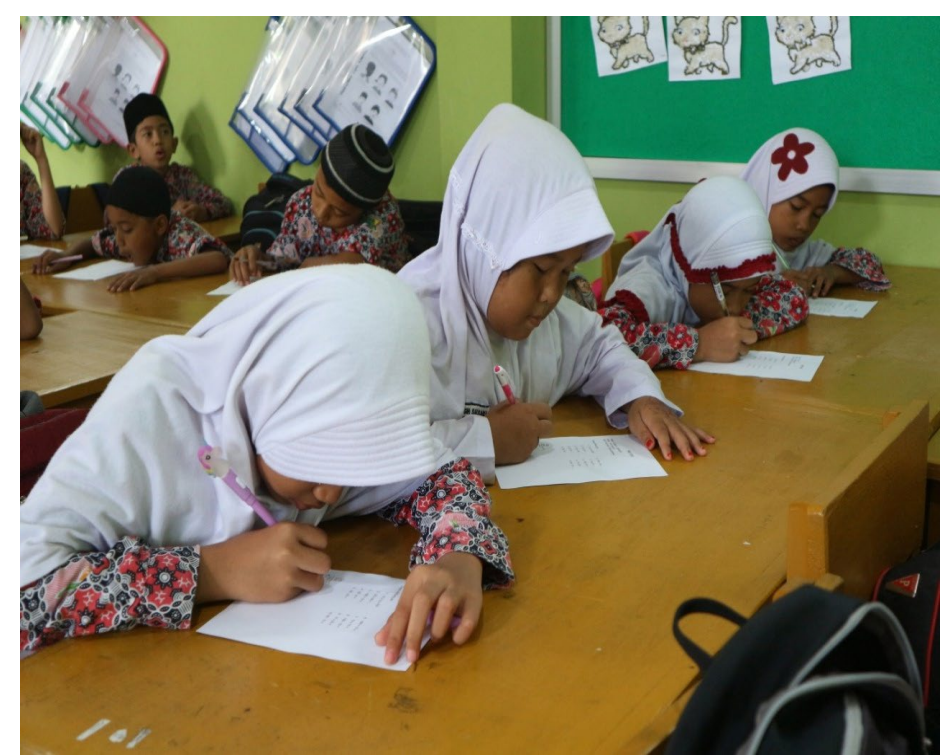

Gambar 3.3. Siswa Sedang Melakukan Pretest

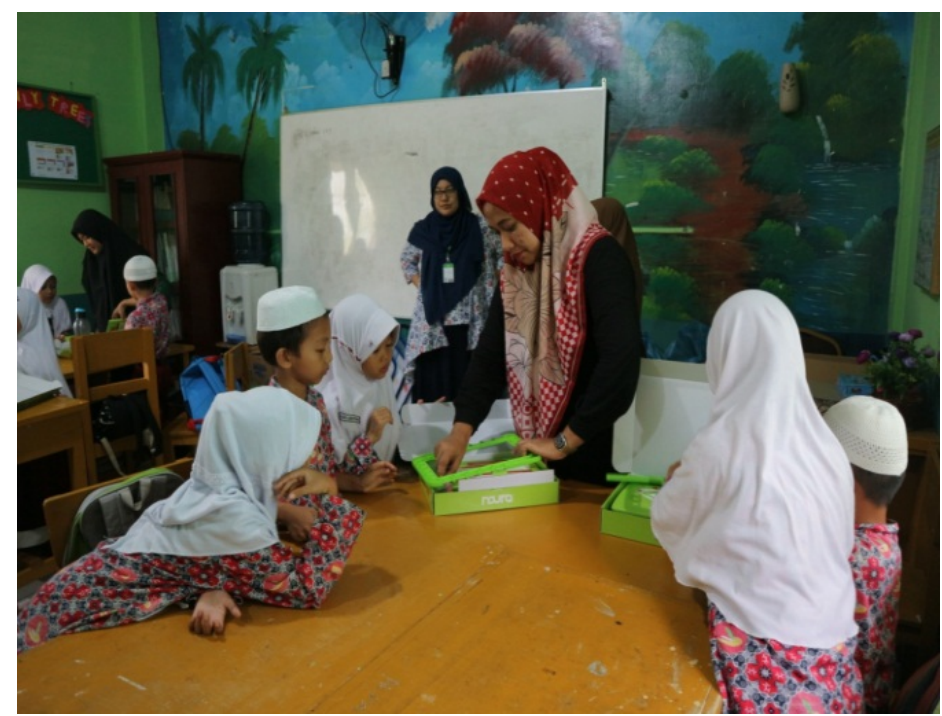

Gambar 3.4. Tim Pelaksana Sedang Melakukan Sosialisasi Penggunaan Alat

4. Evaluasi dilakukan sekitar dua bulan setelah selesai pelaksanaan pengabdian. Tim pelaksanan akan kembali ke SDIT Deli Insani, Kecamatan Tanjung Morawa, Kabupaten Deli Serdang untuk melakukan evaluasi dan monitoring. Pada tahap ini, tim pelaksana akan mengevaluasi bagaimana proses belajar mengajar khususnya bidang studi matematika dengan meggunakan peralatan yang sudah disediakan sebelumnya. Dalam tahap ini juga dilakukan umpan balik 
untuk mengumpulkan masukan terhadap kegiatan pengabdian kepada masyarakat yang telah dilakukan di tempat mitra tersebut.

\section{KESIMPULAN}

Adapun kesimpulan yang diperoleh dari kegiatan pengabdian masyarakat di SDIT Deli Insani yaitu:

1. Kegiatan pengabdian masyarakat yang telah dilakukan mendapatkan respon yang luar biasa dari siswa, guru, kepala sekolah serta orang tua siswa karena selain mendapatkan bantuan 10 unit media pembelajaran berupa worksheet keping warna, siswa juga senang mendapatkan kunjungan dari para Tenaga Pengajar Program Studi Matematika, FMIPA, USU.

2. Terjadi peningkatan kemampuan pelajaran matematika para siswa dan guru sebagai objek dari pengabdian masyarakat ini.

3. Guru mempunyai media pembelajaran yang dapat digunakan dalam pengajaran.

4. Sekolah memiliki alat permainan yang inovatif dalam menyelesaikan masalah terbatasnya ruang gerak siswa ketika beristirahat.

\section{UCAPAN TERIMAKASIH}

Artikel ini merupakan salah satu hasil dari Program Pengabdian kepada Masyarakat yang Dibiayai oleh dana NON PNBP Universitas Sumatera Utara Sesuai dengan Surat Perjanjian Penugasan Pelaksanaan Pengabdian kepada Masyarakat Program Mono Tahun Dosen Muda Tahun Anggaran 2019 Nomor: 331/UN5.2.3.2.1/PPM/2019, Tanggal 20 Mei 2019. Oleh karena itu, diucapkan terima kasih kepada Rektor Universitas Sumatera Utara atas dukungan dana dan fasilitas yang diberikan. Terima kasih juga kepada Mitra pada kegiatan pengabdian ini.

\section{DAFTAR PUSTAKA}

Sanjaya, Wina. 2008. Strategi Pembelajaran Berorientasi Standar Proses Pendidikan. Jakarta : Kencana Prenada Media Group.

Shirran, Alex. 2008. Evaluating Students-Mengevaluasi Siswa. Jakarta : Grasindo. 